\title{
The Hidden Business Costs Of European Union Enlargement: The Case Of The Czech Republic
}

John Phillips (E-mail: jpjericho421@aol.com), Indiana University Southeast Emil Stark, Indiana University Southeast

Jerry Wheat (E-mail: jwheat@ius.edu), Indiana University Southeast

\begin{abstract}
Enlargement of the European Union (EU) will take place on May 1, 2004. Nine countries from Eastern Europe will become full fledged members of the union. While these countries have met the EU accession criteria many are not really ready to compete with Western European companies. One of the major impediments for firms in the East is the hidden costs of joining the union. This paper explores some of the case of the Czech Republic, what hidden costs are currently apparent, and suggests changes that would make the Czech Republic more competitive in Western

Europe.
\end{abstract}

\section{Introduction}

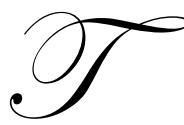

he European Union will expand by adding 10 new countries in May 2004. Nine of the 10 countries are former communist countries who have undergone significant restructuring sine the fall of the Berlin Wall in 1989. The transitions have at times been slow and have been painful. Many of the EU's new countries have looked forward to joining as a way to solve many of their economic problems. In the rush to join these countries may have overlooked some of the hidden business costs of joining. This paper will illustrate these costs for the Czech Republic and suggest approaches to ameliorating the costs.

\section{The Beginning Of Enlargement}

Soon after the fall of the Berlin Wall in 1989, the European community quickly established diplomatic relations with the countries of central Europe. It removed long-standing import quotas on a number of products, extended the Generalized System of Preferences (GSP) and, over the next few years, concluded Trade and Cooperation Agreements with Bulgaria, the former Czechoslovakia, Estonia, Hungary, Latvia, Lithuania, Poland, Romania, Slovakia and Slovenia. These countries came to be known as the candidate countries.

During the 1990s, the European Community and its Member States progressively concluded Association Agreements, so-called "Europe Agreements", with ten countries of central Europe. The Europe Agreements provide the legal basis for bilateral relations between these countries and the EU. The European Community had already established similar Association Agreements with Turkey (1963), Malta (1970) and Cyprus (1972). In the case of Turkey, a Customs Union entered into force in December 1995 (www.europa.eu.int).

\section{The Accession Process}

In 1993, at the Copenhagen European Council, the Member States took a decisive step towards the current enlargement, agreeing that "the associated countries in central and eastern Europe that so desire shall become members of the European Union" (www.europa.eu.int). Enlargement was no longer a question of "if" but "when." The European Council clearly declared its intention "Accession will take place as soon as an applicant is able to 
assume the obligations of membership by satisfying the economic and political conditions required" (www.europa.eu.int). The European Union (EU) also designed the membership criteria. Which are:

- Stability of institutions guaranteeing democracy, the rule of law, human rights and respect for and protection of minorities;

- The existence of a functioning market economy as well as the capacity to cope with competitive pressure and market forces within the Union;

- The ability to take on the obligations of membership including adherence to the aims of political, economic and monetary union commonly called the communautaire acquis.

- $\quad$ The conditions for its integration through the adjustment of its administrative structures, so that European Community legislation transposed into national legislations implemented effectively through appropriate administrative and judicial structures. Called the Communitare Acquis.

\section{Current Events}

The European Union is preparing for its biggest enlargement ever in terms of scope and diversity. Thirteen countries have applied to become new members: 10 of these countries- Cyprus, the Czech Republic, Estonia, Hungary, Latvia, Lithuania, Malta, Poland, the Slovak Republic, and Slovenia are set to join on May $1^{\text {st }}, 2004$. They are currently known by the term "acceding countries". Bulgaria and Romania hope to do so by 2007, while Turkey is not currently negotiating its membership. Several of the countries, including the Czech Republic (CR), have held the EU required referendum. Voters passed the referendum by a $58 \%$ majority (www.europa.eu.int).

\section{Why The EU Must Expand}

The EU is compelled to expand for several reasons, each with it's own benefits. Enlargement of the EU and expansion of the common market will increase the scope of the Union's role in world affairs, in security, foreign, and trade policies, as well as other areas of global concern. New members will enrich the cultural diversity of the EU, foster better understanding amongst its peoples, and increase the exchange of ideas. Quality of life will improve throughout Europe as EU standards and policies are adopted to protect the environment and reduce the threat of crime of all types. With an influx of more the 100 million people, with rapidly growing economies, the common market of more than 370 million will experience increased economic growth and greater opportunity for employment in both the pre-accession 15 and the new member states (www.europa.eu.int). Finally, the extension of the zone of peace and stability in Europe will enhance the security of all of its peoples.

The Union's presence in central and eastern Europe has already produced recognizable benefits. Stable democracies have emerged, with democratic institutions and increased respect for diversity. The economic reforms already in progress in these countries have led to higher rates of economic growth than the current EU average and better employment prospects (www.europa.eu.int). The reform process has been further strengthened by the prospect of EU membership, and by the EU's financial support. And as a result, the EU enjoys growing trade with the prospective new members ( $€ 17$ billion trade surplus in 2000), and this in turn spurs further growth within the EU. (www.europa.eu.int)

The Union has prepared for the arrival of new members by making the institutional changes necessary for enlargement: that means ratifying the Treaty of Nice; meanwhile, the applicant countries are already participating in the ongoing debate on the future of Europe.

Numerous economic analyses have concluded that the benefits of enlargement outweigh the costs. Although the benefits are relatively larger for the acceding countries, because they start from a lower economic base (their economies represent only about $6 \%$ of the GDP of EU-15), there are gains for both sides. Moreover, the future members, already exposed to the challenge of globalization, will help the Union to surmount it. (www.europa.eu.int) 


\section{Costs Of Non-Enlargement}

A delay in enlargement, or non-enlargement, would have costs both for the Union and for the applicant countries. Failure to enlarge the single market would lower economic growth in the applicant countries and would deprive member states of economic gains. For the applicant countries, failure to accede would reduce the momentum for economic reform, discourage foreign direct investment (FDI) and reduce opportunities for economic growth. The loss of momentum could create political instability in Europe, and even slow or reverse the process of democratization in central and eastern Europe. Without enlargement, the EU would be less able to combat the problems of organized crime, illegal immigration and terrorism. All of these costs would feed Euroscepticism in the member states, and negatively affect relations with the applicant countries (www.europa.eu.int).

\section{Historical Background Of The Czech Republic}

After World War II, the political system in Czechoslovakia was greatly affected by the introduction of a Soviet-style Communist regime, as it was in the other countries of central and eastern Europe. The system of power was distorted. In effect this imbalance meant that the three branches of power necessary for democratic development - executive, legislative and judicial - were substituted by a unified Communist power. Its power was based on the constitution and for forty years it ruled all layers of social and political life throughout the country with the help of oppressive institutions. After February 1948, the Communist Party became the only autonomous political entity. It allowed a few other parties to exist within the so-called National Front; however, these parties held no real power and were created to provide an outward image of Czechoslovakia as a democratic state (Much of the discussion in the section is adapted from the CIA World Factbook, 2003).

In November 1989, under pressure from massive demonstrations, the Communist regime agreed to a peaceful and gradual democratization of the political system, which led to the downfall of the Communist regime. Through this process, known as the Velvet Revolution, the country took up the task of resuming its pre-Communist traditions and building a genuinely democratic political system. After the revolutionary events of November 1989, which brought about the downfall of the Communist regime, the entire country faced the uneasy task of resuming its pre-Communist traditions and building a democratic political system. A wide diversity of political parties was well established even before the break-up of Czechoslovakia on December 31, 1992. The constitution of the C R, which became valid on the day of the birth of the new state, explicitly defined civil rights, the relationship between the executive and legislative branches of power, and the independence of the judiciary.

The Czech Constitution establishes a Parliamentary Republic. The President is Head of State with largely symbolic powers and is elected by the Parliament. The Parliament is composed of the Chamber of Deputies and the Senate. Deputies are elected for four-year terms by proportional representation whilst Senators are elected for sixyear terms on the basis of a majority system. The Chamber of Deputies is the supreme legislative authority and has the final say on budgetary and legislative matters. These new institutions have successfully provided the framework for a stable and vigorous democracy.

\section{Structure Of The Czech Economy}

Czechoslovakia entered the reform process after the Velvet Revolution in 1989 with favorable initial conditions as the Communist regime had maintained prudent macroeconomic policies. The economic transformation proceeded with the liberalization of prices, the restitution of most properties to their pre-1948 owners and the mass privatization of most companies through two waves of voucher privatization. After the Velvet divorce with Slovakia in 1993, the Czech Republic experienced the so-called Czech miracle, a combination of a rapid transfer of ownership to the private sector, low unemployment and no hyperinflation. Following a balance of payments crisis the country experienced a recession between 1997-1999. This revealed an unfinished reform agenda, notably concerning the financial sector where the major banks were still state-owned as well as the corporate sector, which was unprofitable due to a lack of restructuring. Moreover, improvements in the legal framework had not been as rapid as the change in economic structures, and had allowed the development of 'tunnelling' (asset-stripping). The 
authorities took a number of corrective measures. Privatization of the banking sector was completed in 2001 after a public bailout of the banks and their bad debts. Particular attention was paid to the restructuring of the largest lossmaking companies. Finally, the legal framework was improved especially in terms of combating economic crime and establishing more efficient bankruptcy procedures. A determined effort was aimed at attracting foreign direct investment, which reached 10\% of GDP and made the Czech Republic the main recipient of FDI per capita in Central Europe. For instance, new foreign direct investment has been attracted from Toyota Motor Corp and PSA Peugeot Citroen - a Euro 1.5 billion greenfield car assembly plant in the Central Bohemian town of Kolín (the largest greenfield investment in the country). In a bid to diversify, the public investment promotion agency, Czech Invest, has recently been targeting investment incentives on hi-tech services. Spurred by FDI inflows, the Czech economy has resumed growth since 2000 in a context of low inflation and stable but significant unemployment. The economy has weathered the recent global slowdown well, with real GDP growth at 3.3 percent in 2001, and $2.7 \%$ in 2002. Strong fixed investment and buoyant household consumption - underpinned by robust wage growth and modest gains in employment - helped sustain domestic demand. Moreover, the external current account deficit narrowed in 2001. Inflation remains subdued at 2\%. However, the public deficit has been rising and needs to be stabilized. Also, enterprise restructuring has led to rising structural unemployment and large regional disparities in unemployment rates. The Union for Industrial and Employers' Confederation of Europe (UNICE), the European employers organization, supports the accession of the Czech Republic, which it considers "a frontrunner", with the Czech economy making good progress. Further reforms need to concentrate on the administrative and legal framework and corporate restructuring.

\section{Reasons For The Czech Application}

The Czech Republic would derive many benefits from EU membership. Border and customs control would be greatly simplified, and free movement of capital would allow EU members to invest in CR more freely, improving economic growth, increasing employment opportunities, and developing the infrastructure. Direct financial assistance from the EU will also improve the CR's infrastructure (PHARE, etc.). The removal of trade barriers would greatly increase the opportunities for the CR to trade with other members of the union. Finally, EU membership and the resulting standardization of EU Common Law within the CR will improve the country's stability and the attractiveness of the CR to foreign investors.

\section{Why The EU Wants The Czech Republic}

The Czech Republic is an attractive candidate for EU membership for many reasons. The CR has been very influential in the region Europe, owing partly to its central location, connecting western and eastern Europe. The CR is a large potential market, with great potential for growth. And even though the CR has a well-developed industrial capacity with skilled and technically proficient workers, the cost of labor is relatively low compared to some EU nations such as Germany, UK, and France.

\section{The Effects Of Czech Privatization}

As with most former communist countries the Czech Republic (CR) has privatized former State Owned Enterprises (SOE). Starting in 1993, the CR devised the so called voucher privatization scheme (Wheat, 1994) to be used for large scale privatization. This scheme allowed citizens to buy vouchers and to bid for the purchase of shares of SOEs with the vouchers. Shares of a popular company such as a brewery might "cost" several vouchers each while a steel mill's shares would "cost" a fraction of a voucher. Large scale privatization involved the state selling larger SOEs.

The primary social purpose of the voucher privatization was two fold. First, the government wanted citizens to retain control over CR firms. Second, the scheme was thought to create a wealth owning middle class in the country. At first it appeared that the voucher privatization would fail because citizens showed no interest in buying vouchers. Later several mutual fund companies were formed for the purpose of collecting vouchers to be used to buy shares in sound CR firms. Public interest was created to invest in vouchers when the funds guaranteed a high level of returns to investors. To provide the promised returns the funds sold their shares to western investors 
interested in taking over operations of the Czech companies. Ultimately many of the funds were unable to provide the promised returns and went bankrupt.

Voucher privatization failed to accomplish its primary social objectives but also failed to accomplish many of the more important economic objectives required for economic growth. Privatization should accomplish three objectives from an economic perspective (Casth, 2003):

1. Provide significant funds to government to be able to take over many of the social programs previously assigned to SOEs.

2. Provide new capital to the privatized SOE.

3. Provide new product and process technology to the firm.

Voucher privatization did not accomplish these objectives. The vouchers were sold to citizens at a very low price to enable all citizens to afford purchases and government received very little funding from the sale. Second, since vouchers not cash were used to buy shares cash did not flow to the firm. Finally without additional cash firms could not afford to revamp their technology. The result was that large firms privatized using vouchers ended up in the hands of U.S., Japanese and European multi-national companies.

For example, The Skoda Works, a large well known Czech firm that manufactured autos and heavy military equipment was taken over by Volkswagen. VW then installed the technology from its German plant at Skoda and manufacturers autos under the Skoda name. While on the surface this process seems to accomplish one of the economic objectives of privatization, it exposes the CR to the strains of globalization. Many other large Czech firm were purchased by western and Japanese interests and globalized.

\section{Business Costs Of Joining The European Union}

The CR has become one of the several maquiladoras of Europe. Western Europe manufacturers use the countries of Central and Eastern Europe (CEE) as a place to find low cost labor. In the U.S. parts are shipped south of the U.S./Mexican border where factories assemble the parts into components to be installed on products whose final assembly occurs in the U.S. This enables firms to take advantage of low cost Mexican labor for assembly operations. This same approach is occurring in Europe. Czech labor is technically well trained but wages and fringe benefits are much lower than in Germany.

These large Czech firms that have been globalized and turned into maquiladoras are mostly ready to join the European Union. Many of the costs of getting ready to join the EU, new technologies for example, have already been paid. One indicator of the introduction of new technologies is the level of Foreign Direct Investment (FDI) inflow to the CR during the transition period from 1989-2000. The cumulative inflow of FDI to the CR in the period was $\$ 21.68$ billion or \$2,102 per capital the highest in the CEE region (Transition Report, 2001). The CR has the highest FDI per capital of any of the accession countries. The latest reports from the CR indicate that the country is losing jobs that came from Western Europe in the 1990's to China because labor costs are cheaper.

Small and Medium Enterprises (SME) were privatized in other ways than the voucher approach and a different result occurred. Very small firms were sold to the employees who worked at the firm. SMEs overall were privatized either by public auction or sealed tender offers (World Bank Development Report, 1996). Many of these firms have focused on survival over the 1989-2002 period and have not had the funds to prepare for the more competitive world of the EU.

In 2000 the European Information Center surveyed 600 small and medium sized Czech firms to learn about their preparation to join the EU (Kalnicka, 2000) only $20 \%$ of the firms surveyed had started preparations to join the EU even though $33 \%$ said the EU single market would directly affect their firm. SMEs know the EU is coming but they are doing relatively little to prepare. SMEs have little knowledge of EU business regulations, tax structures and legal issues affecting business in the EU and would have difficulty accessing the information because $33 \%$ do not have access to the internet. Another $25 \%$ on average use the internet less than once a day. 
While the SMEs in the survey saw definite advantages to joining the EU many see more disadvantages than advantages. Overall $17 \%$ were concerned that EU competition would cause Czech firms to close and $12 \%$ were concerned that Czech firm would be unable to meet EU quality standards for their products (Kalnicka, 2000). Other issues raised by the respondents revolve around highly skilled employees leaving the country for EU jobs, increased labor costs and the need to increase fringe benefits for employees.

Hidden business costs of joining the EU will be wide spread, difficult to identify in some cases and expensive to correct. Each cost structure is analyzed below.

The most damaging of the hidden costs is the issue of assisting Czech SMEs to remain competitive in Czech markets. Many of these firms still have out-of-date technologies and currently compete only inside the CR. When the CR joins the EU, new firms from EU countries will enter the Czech market with higher quality products and in many cases lower prices. Czech companies operate at a very low level of economies of scale and have higher productions costs. Both efficiency and productivity will need to be increased for Czech firms to be competitive inside their own country. The CR is currently ranked $21^{\text {st }}$ for countries under 20 million people in competitiveness (IMD World Competitiveness Yearbook, 2003)

Without increasing competitiveness many Czech firms will lose market share to EU firms and will go out of business as a result. This will create lost jobs and be a negative to the Czech economy. Also, where high level expertise is needed, Czech citizens with these skills may move to higher paying jobs in other EU countries.

The European Bank for Reconstruction and Development (EBRD) has recognized this issue and has made a commitment to the development of SME's competitiveness in the CR. The Bank had made commitments of EUR 826 million to this effort. Czech SMEs can now get development loans of EUR 300,000 to 1 million. The EBRD is also supporting a wide variety of additional financing sources (venture capital, leasing) to assist Czech firms competitiveness (Czech Republic Strategy...2001).

Many of the hidden costs will be difficult to identify because they will not be obvious. One of the principle non-obvious costs will be a lack of trained personnel. As an example business will need to understand EU regulations on a variety of topics ranging from product labeling to accounting practices. EU regulations on business encompass several volumes and are not published in Czech. This will result in wide spread mistakes that will be costly to fix, slow response times to inquires and orders and rejections of shipments because the material does not meet regulations. The $\mathrm{CR}$ will need to train thousands of government officials and individuals for private companies to remain competitive. (Prague Post, 2003)

Corruption will also continue to hinder the Czech Republic's ability to compete in the EU. Currently Transparency International ranks the CR 52 on it's corruption index (Corruption Perceptions Index, 2003). The CR scored 3.7 out of 10 (10 is the cleanest) on the corruption surveys. Corruption hinders economic development by shifting decision away from economically sound policies. EU firms will not trust Czech firms and government agencies, and may be unwilling to do business with them. The Heritage Foundation ranks the CR $35^{\text {th }}$ on its Economic Freedom Index (Index of Economic Freedom, 2003). One of the difficulties in the CR noted in the Economic Freedom Report is property rights. While contracts are generally secure administrative procedures in the courts are very slow and investors are frustrated by the lack of effective recourse. Judges are said to unfamiliar with commercial issues.

Investments will need to be made in a variety of areas including training and upgrading technologies. While the EU PHARE Program and the EBRD will help, the CR will have to make some very serious decisions about the country's future. The CR currently ranks 33rd on the United Nations Human Development Index and $38^{\text {th }}$ in GDP/capita on a Purchasing Power Parity basis in 2000 dollars (United Nations Human Development Index, 2002).

Currently Czech firms, acting as maquiladoras make products designed and developed in other countries. Comparatively little research and development is performed in the country. The Gross Domestic Expenditure on $\mathrm{R} \& \mathrm{D}$ as a percent of GDP in the CR for 1999 was $1.27 \%$. The EU average was $1.86 \%$ and these countries have 
much bigger economies (World Development Indicators 2003). The CR runs the risk of similar problems as Mexico where free trade with the U.S. and Canada has failed to provide the long term economic growth the country had hoped for (Authers and Silver, 2003).

Declining corruption and economic reform were supposed to follow an open market created by the NAFTA treaty but Mexico's economic problems continue unabated.

\section{Czech Legal System}

As part of the EU's analysis of the candidate countries EU member states have critiqued the Czech judiciary. In the regular reports of the Commission, the Czech judiciary is considered to need "significant attention" or "continuous attention" which in the EU's terms means significant concern for the current state of judiciary. In response to this, the CR initiated reform of the civil service and judiciary but obstacles have slowed reforms. Structural changes implemented by the new Judicial Act (adopted 2002), have been declared void by CR's Constitutional Court, but the CR has not asked for any transitional period or permanent exception from the judicial system chapter of the acquis communitare moves towards membership in the EU. The $\mathrm{Cr}$ will need to initiate additional reform and the new reform will have to be tailored to the requirements of the EU.

Another key concern is the general capacity of Czech judiciary to enforce the EC/EU law. The judiciary will need to gain knowledge of EC/EU law. CR universities will be the primary place where CR judges get core education in the EC/EU law. EC law is a mandatory part of law curriculum in Czech universities.

\section{Czech Accounting System}

Traditionally, SOE's did not have to report financial information to the public. Now many of the Czech enterprises are owned by large institutional owners and the position and power of small shareholders is minimal. Both of these conditions have made a general reluctance to disclose the predominant attitude. The quality and span of annual reports is different from firm to firm.

Accounting standard setting in the Czech Republic is a very much top-down process. The Ministry of Finance is the only party that has a say in the all-encompassing Accounting Act. Because of this, the influence level of universities and professional bodies is very limited. This makes CR accounting infrastructure very inefficient. The current accounting system has provides little information for managerial decision making.

\section{What Next For The Czech Republic?}

From a policy perspective what should the CR do next? Three changes will help the CR become less dependent on Multi National Firms (MNF) and be a competitive equal in the EU.

First, the CR must invest in a quality system of education. The current higher education in the CR fails to meet university standards set by the EU in the Bologna Agreement of 1999 (Weldon, 2003). The Czech system is inflexible. Curricula has not been revised in many years and programs are out-of-date. Petr Mateju, a prominent Czech sociologist, pointed that "...competitiveness is declining..." in the CR because "...Czechs are too busy being Czechs and not busy being internationally conscious" (Mateju, 2003). The Czech language is unique to the country and until recently other languages were not emphasized in education.

A second issue the CR must face is the issue of research and development. Very little research is performed in the country. The country does not have its own knowledge base. What research in product development that is performed in the country is done by firms that have globalized.

Finally, the CR must build its own knowledge infrastructure. Not an information technology system but a system to create, store, knowledge. Scientific knowledge, information about business practices, patents, legal issues, health care issues and research methodologies. Kalnicka (2000) reported that $67 \%$ of Czech businesses did not know 
where to obtain information about the EU and thought the government should provide the information. The Czech Republic needs to enter the knowledge based economy of the $21^{\text {st }}$ Century.

\section{Conclusion}

While the Czech Republic certainly will see many new opportunities in joining the European Union, there will also be significant costs. This paper has illustrated some of the costs to business that may not have been recognized in the run up to joining the union. The issues facing Czech businesses are not insurmountable but need to be recognized and approached with logical, orderly planning.

\section{References}

1. Authers, John and Sara Silver, "Mexico's Lost Decade: as investment switches to China, the opportunities created by NAFTA are under threat", Financial Times, July 2, 2003, pp .2.

2. CIA World Factbook, 2003, www.cia.gov/cia/publications/factbook/index.html.

3. Csath, Magdolna, "Economic Development and Social Consequences: A Hungarian Balance Sheet", in From Communism Toward the European Union: A Decade of Change, Hungarian Atlantic Council, Budapest, 2003.

4. Corruption Perceptions Index", Transparency International, Berlin, 2003

5. Czech Invest, 2003, www.czechinvest.org.

6. "Czech Republic Strategy Overview", European Bank for Reconstruction and Development, 2001 accessed at www.ebrd.org/about/strategy/country/czechrep/main.htm, July 25, 2003.

7. IMD World Competitiveness Yearbook 2003, IMD, Lausanne, Switzerland, 2003.

8. Index of Economic Freedom, Heritage Foundation, Washington, D.C., 2003.

9. Kalnicka, Vladmira, "Opinions of the Business Community of the Situation Concerning the Czech Republic Joining the European Union", European Information Center, October 6, 2000, pp 3-4.

10. Mateju, Petr, "Editorial: Czech Higher Education at the Crossroads", Czech Sociological Review, Vol. 39, No. 3, 2003.

11. Transition Report 2001, European Bank for Reconstruction and Development, Basel, Switzerland, 2001.

12. Weldon, Bill, "Considerations for Higher Education Systems in Post-Communist Societies: A Current Look at Czech Higher Education", Czech Sociological Review, Vol. 39, No. 3, 2003.

13. Wheat, Jerry E., "Market Reform in the Czech Republic: Myth or Reality", Proceedings of the 1994 Midwestern Academy of International Business Conference, Chicago, March 1994.

14. World Development Indicators 2003, World Bank, Washington, D.C, 2003.

15. World Bank Development Report, World Bank, Washington, D.C. 1996.

Notes 